\author{
Zabihullah RAHMANI \\ Sakarya Üniversitesi \\ Sosyal Bilimler Enstitüsü, \\ Yüksek Lisans Öğrencisi \\ Sakarya/TÜRKIYE \\ rzabihullah035@gmaill.com
}

\section{KENDİ DÖNEMİNDE YAZILAN KAYNAKLARDA ALİ ŞîR NEVÂî VE FAZLA BILIINMEYEN ÜÇ ESERİ*}

\author{
ALI SHIR NEVÂ̂̂'S LESS KNOWN THREE \\ BOOKS
}

\section{$\ddot{O Z Z}$}

Ali Şı̂r Nevâî büyük mütefekkir, edip, şair, tarihçi, yazar, devlet ve siyaset adamıdır. Onun kaleme almış olduğu tarihî ve edeb̂̂ eserlerinin hemen hemen hepsi Horasan havzasindaki Türk-İslam kültür ve medeniyetinin oluşmasına katkı sağlamıştır.

Nevâi ömrünün neredeyse tamamını özellikle Türk dili ve halkını zirveye çılkarmaya vakfetmistitir. Alî Şîr Nevât bu gayesini gerçekleştirmek için birçok eser kaleme almıştır. Vefatından sonra da hayatı ve eserleri üzerinde birçok çalışma yapılmıştır. Biz de bu çalışmada Nevâ̂ ile ilgili kendi zamanında yazılan Bâbür-Nâme, Devlet Şah Tezkiresi ve Hüseyin Baykara Risâlesi gibi tarihîedeb̂̀ eserlerde onunla ilgili olan kisimlar hayat hikâyesine katkıda bulunacağ d düsüncesiyle bir araya getirdik.

Ayrıca, bu çalışmada Ali Şîr Nevâ̂̀'nin Türkiye'de pek bilinmeyen Çă̆atayca Risâle-i Tîr Endahten isimli eseri ile Farsça telif edilmiş Risâle-i Müfredât-ı Mu'amma ve Risâle-i Münșeât-ı Farisî isimli eserlerini akademik camiaya tanitmaya çalıștık. Böylece Alî Şı̂r Nevâi ile ilgili farklı kaynaklardaki bazı bilgileri ortaya koymakla beraber, Özbek ve Farsça kaynaklardan tercüme yoluyla șairin Türkiye'de az bilinen üç eserini de Eski Türk Edebiyatı alanına tanıtmış olduk.

Anahtar Kelimeler: Alî Şı̂r Nevâî, Türk Edebiyatı, Bilinmeyen Eserleri

\section{ABSTRACT}

Ali Shir Nevâ̂ $̂$ was a great poet, writer, historian, intellectual, statesman and politician of his era. Many of his historical and literary works had provided clear contributions to formation and development of IslamicTurkish culture and civilization at old Khorasan.

Nevâi has devoted almost all his life to his people and the enhancement of the Turkish language. He wrote numerous books. Since $15^{\text {th, }}$ they are being worked on. So many of them are well known. However, in this article apart from information known before about him, we tried to express new things by translating some parts related to Ali Shir Nevâ̂ from Bâbür-Nâme, Devlet Shah's Tezkire and Hüseyin Baykara's Risâle, historical-literary sources during his own period.

In addition, another appealing side of this article, to introduce Ali Shir Nevâ̂'s three works that are no very familiar in Turkey, benefitting from Uzbek and Iranian sources. Risâle-i Tir Endahten written Chagatai, Risâle-i Mufredat-i Mu'amma, and Risâle-i Munsheat-i Farisi written Persian.

Overall, obtaining some other information on Ali Shir Nevâ̂ from various sources, and introducing his less known three books by translating from foreign sources, means putting new adding to his life and works, would be beneficial in our Classic Turkish Literature.

Keywords: Ali Shir Nevâî, Turkish literature, Unknown books

\footnotetext{
Atıf@ $\quad$ Rahmani, Zabihullah. “Kendi Döneminde Yazılan Kaynaklarda Alî Șir Nevâî ve Fazla Bilinmeyen Üç Eseri", Hikmet-Akademik Edebiyat Dergisi [Journal Of Academic Literature], Yıl 5, Sayı 10, Bahar 2019, s. 291-303.
}

\footnotetext{
* Bu makalenin şekillenmesi aşamasında yol gösteren değerli Hocam ve tez danışmanım Doç. Dr. Vildan Coşkun'a teşekkürlerimi sunarım.
} 


\section{GİRIȘ}

Alî Şîr Nevâî Horasan'ın merkezi Herat şehrinde, 9 Şubat 1441 doğmuş, hayatının büyük kısmını aynı yerde hem bir siyasetçi hem de edebiyatçı olarak geçirmiş ve orada 3 Ocak 1501'de vefat etmiş̧tir. Ömrünün son dönemlerini ise saray ve siyaset işlerinden kendi isteği ile çekilip daha çok ilmî-edebî eserler kaleme alarak geçirmiştir. Türkçe olarak yazdığ 1 eserlerinin çeşitliğinden yola çıkarak klasik Türk yazar ve şairlerinin kervanbaşısı konumunda olduğunu söylemek mümkündür. (Vahidov ve İşançkulov, 2000: 208-209).

Ali Şîr Nevâî’nin yetişme şartlarında yaşadığı dönem ve ilmî-edebî muhit oldukça etkili olmuştur. Nevâ̂’'nin babasının sanatsever biri olması ve evinde sürekli edebî meclisler kurması, onun entelektüel alt yapısının temellerini atmıştır. Daha sonra Ebul Kasım Babür tarafından sarayda eğitilmiştir. Kendisinden önce yaşamış Çağatay edip ve şairleri Mevlana Lütfî, Mevlana Sekkâkî, Mevlana Gedâî, Mevlana Atâî, Mevlana Harezmî ve Fars edebiyatının en büyük edip ve şairlerinden Hafız Şirazî, Hüsrev Dehlevî, Abdurrahman Câmî ve benzerleri, Nevâî'nin edebî şahsiyetini etkileyen önemli isimler olmuştur. (Vahidov ve İşançkulov, 2000: 210). Demek oluyor ki, bütün bu hususlar, daha çocukluktan itibaren Nevâînin fikrî, ilmî ve edebî yönden yetişmesini sağlamıştır.

Nevâî'nin edebiyattaki başarılarını siyaset sahnesinde de sürdürdüğünü görmekteyiz. Semerkant'tan döndükten sonra sarayda göreve başlamış, sırasıyla, sarayda mühürdar, divan beyi, maliye sorumlusu, padişah vekili, Esterabat hâkimi gibi görevlerde bulunarak neredeyse ikinci devlet adamı olarak çalışmıştır. (Vahidov ve İşançkulov, 2000: 230).

Nevâî; "bu dünyada insandan geriye güzel isimden başka hiçbir şey kalmaz" sözünden yola çıkarak Horasan'ın dört bir yanında irili ufaklı 370 adet cami, medrese, hankâh, kervansaray, köprü, türbe, hastane gibi kamu hizmet kuruluşları bina ettirmiştir. Bunlar arasında Herat Dârü'ş-şifası, Herat Dârü'l-hifâzı, Herat Câmîsi, Hâlâsiyye Medresesi, İhlasiyye Hankahı vb. önemli mimari eserler de vardır. Nevâî sarayda maliyeden sorumlu iken, yaptırdığı kurumlardaki muallimler, muhaddisler, fıkıhçılar, hekimler, hikmet, felsefe öğretmenleri ve bilim sahiplerinin hepsinin devletten maaş almalarını temin etmiş ve ayrıca aklî-naklî ilim alanlarında tahsil gören öğrencilere derecelerine göre yardım yapılmasını sağlamıştı. Sadece bununla da kalmayan Nevâî'nin sarayda kurduğu ilim meclislerine ülkenin dört bir yanında yaşamakta olan yüzden fazla din âlimi, şair, tarihçi, tezkireci, hikmet ve felsefeci, nakkaş, hattat ve musavvir iştirak edip, yazdığ 1 veya hazırladığı eserlerinin maddî-manevî karşılığını alırlardı. Onun döneminde ülke maddî ve manevî açıdan istikrara ve refaha kavuştuğundan tarihçiler tarafından o yıllar doğunun Rönesans'1 olarak adlandırılmıştır. (Nevâî Nizamü'l-Mülk-i Sâni: 66-70). 
Nevâî’nin Türkçe olarak kaleme aldığı ilmî-edebî eserlerinin bazıları alanında ilktir. Örneğin, Türk dilinde ilk Hamse Nevâî tarafından yazılmıştır. Bunun gibi ilk şairler tezkiresi Mecâlisü'n-Nefâyis ve ilk mutasavviflar tezkiresi Nesâyimü'l-Mahabbe'yi de o yazmıştır. 55000 beyitten oluşan şiirleri Külliyat adı altında toplamıştır. En önemlisi Türk dilini Fars dili etkisine karş1 savunmuş ve Türkçenin Farsçadan daha yüksek bir dil olduğunu Muhâkemet 'ül-Lugateyn eseri ile ispat etmiş̧tir.

Nevâî'nin edebî etkisi ve şöhreti daha hayatta iken Memleketi Herat başta olmak üzere Anadolu, Azerbaycan, Mâverâünnehir ve Hindistan'a ulaşmıştır. Başta Muhibbi, Baki, Nedim olmak üzere Osmanlı sahasının önde gelen yaklaşık 70 edip-şairi Nevâî'den etkilenmiş ve onun şiirlerine nazireler yazmıştır. ${ }^{1}$ Bunun yanı sıra 19.yy'a kadar Özbek edebiyatındaki şairlerin hemen hepsinde Nevâî etkisini açıkça görmek mümkündür. (Çetindağ, 2006: 3)

Bazı İran edebiyat tarihçileri, Nevâînnin doğduğu şehrin Herat olması ve o dönemde İran'ın Timurlular tarafından idare edilmesi ve ayrıca şairin bazı eserlerinin Farsça yazmasından dolayı onun İranlı bir şair olduğunu ileri sürmektedir. Nevâî'nin babasının Kiçkine Bahadır Uygur boyundan geldiğini iddia eden Uygur Türklerine göre de, o Uygur şairidir. Özbekler, Nevâî'yi Özbek dilinde yazdığı eserlerinden dolayı manevî ataları olarak görürler. Türk araştırmacılar da Nevâî'nin eserlerinin içeriğinden yola çıkarak onun bir Türk şairi olduğunu düşünürler.

Yukarıdaki görüşlerin her birinin hakikat tarafı olmakla birlikte, Nevâî’nin düşüncelerini göz önüne aldığımızda, milleti veya ırkı ne olursa olsun, onun İslam medeniyetinin en büyük düşünürlerinden biri olduğunu söylemek mümkündür.

Nevâî’nin milliyetçilik düşüncesi tüm Türk dünyası için mâye-i iftihardır. Onun tüm eserlerinde, başta "Türk, Türük, Etrâk", kelimeleri olmak üzere Özbek, Barlas vb. Türk boylarının isimleri ile çok sık karşılaşılmaktadır. Nevâî otuzdan fazla eserinde yaklaşık 350 yerde doğrudan veya dolaylı olarak "Türk" kelimesini kullanmış veya Türk halkına seslenmiştir. (Bkz. Köktekin). Eserlerinin hemen hepsinin mukaddimesinde bunları Türkler için

\footnotetext{
${ }^{1}$ XV. ve XVI. asırlarda Nevâî'den doğrudan veya dolayalı olarak etkilenen ve onun eserlerine tanzir eden şairlerin sayısı 70 civarındadır. Şu şairler ve nazirelerinin sayısı dikkate şayandır: Fuzûli 73; Muhyî 61; Kemalpaşa-zâde 47; Lâmî̂ Çelebi 46; Ahmed Paşa 39; Muhibbî 35; Ulvî 32; Cafer Çelebî 25; Necâtî 24; Hayâlî 22; Gelebolulu Alî 20; Sehî 17; Kâtibî 15; Taşlıcalı Yahyâ 13; Usûlî 13; İshak Çelebî 11; Cinânî 10; Avnî 9; Adlî 9; Karamanlı Nizâmî 9; Nevî 9; Şarklı Surûrî 9; Cem Sultan 9; Mihrî Hatum 9; Âşık Çelebî 7; Ahî 6; Basirî 6; Bâkî 6; Sâlih 5; Nazmî 5; Hilâlî 5; Mesihî 5; Hamdullah Hamdî 4; Harâmî 4; Zaifî 4; Fedâyî 4; Adnî 4; Ş. Yahya 4; Behiştî 3; Nihânî 3; Kemâl 3; Revânî 2; Subhî 2; Bahtî 2; Sarâyî 2; Azâd Çelebî 2; Selmân 2; Hayretî 2; Yetîm 2; Amrî 1; Ali Bey 1; Sevdâyî 1; Şemî 1; Zihnî 1; Şevkî 1; Futuhî 1; Gedâyî 1; Helâkî 1; Nehârî 1; Surrî 1; Muîdî 1; Sunî 1; Şevkî-i Bursevî 1; Şemî Dede 1. (Çetindağ, 2006: 3.)
}

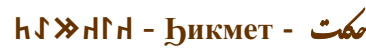


yazdığını, bu eserleri ile Türk halkının gönüllerini birleştirdiğini ileri sürmüştür. Nitekim Muhâkemet'ül-Lugateyn eserinde şöyle demiştir:

"Türkçe ve Farsça dillerinin gerçek özelliklerini şerh etmek için bu kitabı kaleme aldım. Ve ona Muhâkemet'ül-Lugateyn ismini verdim. Öyle ki, Türk dilinin fasih olduğuna dikkat çektim ve belagat genişliğini ortaya çıkardım. Zannediyorum ki, Türk halkının fasih insanlarına büyük gerçeği ispat ettim. Onlar da kendi dillerinin niteliğe ve kendi lisanının sözlügüüün özelliklerine vakıf olsunlar" (Ahmedova, 2000, 33-34)

\section{A. KENDİ DÖNEMINDE YAZILANLAR ESERLERDE ALÎ ŞîR NEVẦ̂ ${ }^{2}$}

Ali Şîr Nevâî ile ilgili kendi zamanında ve vefatından sonra birçok kaynakta bilgi verilmiş ve hayatı, eserleri, edebî kişiliği üzerine de daha sonra birçok çalışma yapılmıştır. Özellikle kendi döneminde yazılmış bazı eserler vardır ki, Alî Şîr Nevâî ile ilgili bu eserlerde zikrolunan bilgiler nerdeyse hiç kullanılmamıştır. Biz burada Alî Şîr Nevâî'ye dair bu eserlerdeki bilgileri Türkçeye tercüme ederek sunacağız.

\section{Hüseyin Baykara Risâlesi'nde Alî Şîr Nevâî:}

Sultan Hüseyin Baykara (ö. 1506) Horasan'ın hâkimi olmasının yanı sıra dönemin gözde şairlerinden de biridir. Onun bir divanı ve bir tane Risâle isminde mensur eseri vardır. (Algar ve Alparslan, 1998: 530-532). Hükümetinin adaleti, din âlimler ve mutasavvıflara karşı sevgi saygısı, âlim ve sanatkârları koruması, Abdurrahman Câmî̀ye karşı sevgisi gibi konulardan sonra, asıl konu, kendi veziri ve dostu Nevâî hakkında şunları söylemiştir:

"Hak söz söyleme üslubuna sahip cesur ve yiğit "Mir Alî Şir” Allah ona güç ve kuvvet versin. "Nevâ̂̀" mahlası ile meşhurdur. Ve şiirlerinde de bu mahlası kullanmıştır. Türk dilinin ölmüşs cismine Mesih nefesleri ile rûh giydirdi. Ve o rûh bulmuşlara da Türk dilinin âdet ve geleneklerinden altın iplik ile ipek elbiseler giydirdi. Söz bahçesinde ilkbahar havasından rûha sükûnet ve huzur veren yağmurlarla rengârenk güller açtı. Ve nazım denizine fikir ile düşünce bulutlarından, rûha sükûnet veren damlalarla çeşitli iri inciler saçtı. Hangi zümrenin şiir meydanında at sürdü ise, o ülkeyi dil kalemi hançeri ile fethedip kendi yetkisi altına aldı. Onun nazmını övmeye dil yetersiz ve beyan âciz kalır.

Nevâî’nin hangi beytidir ki aşk ehli canına alev yakmaz? Ve şiirinin hangi mazmunudur ki, ayrılık acısı çekenlerin cismini yandırmaz, hatta

\footnotetext{
${ }^{2} \mathrm{Bu}$ bölümde Alî Şîr Nevâî hakkında çağında yazılanları bir araya getirmeye çalıştık. Başvurduğumuz Özbek Türkçesi ve Farsça olup kaynaklardan alıntıladığımız bilgilerin Türkçeye çevirileri tarafımıza aittir. (ZR)
}

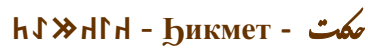


külünü bile göklere savurmaz? Hangi mısraldır ki, ayrı düşenlerin kavurulmuş ciğerinin kanını damlatmaz? Hangi kelimesidir ki, ayrılı̆̆a uğramışların gözyaşları seli ile sabırlı kişileri akıtmaz? Hangi nazım ülkesinin büyük saraylarının kapılarını açma kuvvetini denediğinde onları açamadı? Hangi ülkeye Tük şiiri atı ile saldırdığında fetih edemedi? Bugün nazım topluluğunun dörtte birinin bahadır yiğidi odur. Ve ona, bu ülkenin edebiyat ve şiir alanlarında - Timur-ı sâhip-kıran'ı deseler yeridir.

Ey Allah'im Nevâî gibi bir yüce şahsiyeti ve belagat unsurlartyla dolu eserler yazan yeteneğini bu ülkenin gök kubbesi altına hediye ettiğin için şükürlerimi nasll yerine getireyim? Hangi dil ile başlayayım? Ĕ̌er yüz canım bile olsayd feda ederdim, eğer şükrünü yerine getirdim desem yine hata yapmış olurdum!'” (Risâle-i Baykara, Vahidî Cevzicanî, 1925: 214-226)

Alî Şîr Nevâî, Baykara'ya herkesten yakın olup onun sırlarını bilen bir dostu idi. Görüldüğüü üzere Baykara Nevâ̂’’nin varlığı ile övünmüştür. Küçük yaştan itibaren hayatları birlikte geçen Baykara onun edebî kişiliği ve hâkimiyetteki rolünü anlatan müstakil bir eser kaleme almıştır. Aynı şekilde Nevâî'nin bütün eserlerinde "Şâh Ebul Gâzi" unvanını görmek mümkündür ki, Sultan Hüseyin Baykara için denilmektedir.

\section{Devlet Şah Tezkiresi’nde Alî Şîr Nevâî:}

Devlet Şah'ın (ö.1495) Tezkiretü'l-Şuerâsı'nda Alî Şîr Nevâ̂̂'nin ilmî ve edebî çalışmaları, sosyal konumu, siyasî görevleri gibi hususlarda etraflıca bilgi verilmektedir. Çünkü Devlet Şah'ın kendisi de Nevâî ile aynı dönemde ve aynı şehirde hayat geçirmiş ve Nevâî ile aynı ilmî-edebî meclislerde bulunmuştur. Daha doğrusu bu iki önemli isim, bir biriyle iletişimde olmuşlardır. Hatta söz konusu tezkire 1487 yllında tamamlanıp bizzat Nevâî'ye ithaf edilmiştir. Nevâî hakkında birinci elden bilgi veren bu kaynağa başvurmak Nevâî'nin kimliği ve kişiliğini doğru tespit etmek için kaçınılmazdır. Eski Farsça dilinde yazılmış bu tezkirenin Nevâi maddesinde kısaca şu bilgilere yer verilmiştir:

"Emîr-i Kebîr (Alî Şî̀ Nevâî) ihtişamlı ve yetkili devlet adamı olsa da ilim ve sanat hususunda da daha çok çalışıp çabalamaktadır. Her zaman ilim ve hikmete sâhip ve onlarla iç içedir. Yaratılıştan cömert birdir. Anlayışı, kavrayışı, akılı, fikri ve şiiri akıcıdır. Eserleri okumaya ve hadisleri dinlemeye çok meraklıdır. Daha gençken bile iki dilde, (Farsça ve Türkçe) şiirler yazdiğı biliniyordu. Türkçe'deki sanatı daha da yükselmekle birlikte olarak da değerli ve üstün mülemma' şiirleri vardır.

Sultan Ebul Kasım Babür Padişah, sanat ve şiirden anlayan ve söz sanatkârlarını seven biriydi. O bazen Nevâ̂'nin Türkçe ve Farsça şiirleri veya münşeâtını etraflıca düşünüp okuyordu. Nevâ̂̀'nin kuvvetli zekâsı, tatlı ve güzel sözlerine hayrandl. Daima ona hayırl dualar ederdi.

Bugün Emîr-i Kebîr din ile devletin himâyecisi, hem şeriat hem de milletin gözedeni ve koruyucusudur. Dönem padişahı (Hüseyin Baykara)

$h \checkmark \gg h 4 h-$ 马икмет - ت

HİKMET AKADEMIK EDEBIYAT DERGisi [ JOURNAL OF ACADEMIC LITERATURE]

ISSN: 2458 - 8636 
onun ögüt ve sözlerinden faydalanır. Dostları ve dönemin ileri gelenleri O'nun sohbetlerini beğenip kendi şükranlarını sunardı. O'nun yüce meclisi ilim ve fazilet sahiplerinin istediği menzilidir.

Nevâ̂̀'nin evinin kapısı güçsüzler ve fakirlerin başvurduğu makamdır. Sofrası ve ikramları çaresiz fukaralar önünde her zaman kuruludur. İkram kapısı güçlük çekenlere daima açıktır.

Emîr-i Kebîr; Sultan (Baykara) hazretlerine yakın olmasına rağmen İslam dini, sünneti ve şeriatın güçlenmesine yönelik tedbirler alır. Başka bir ifade ile halkın din ve inanç durumu ile yakından ilgilenir. Şerafetli yaratılışı ve yumuşak huyu ile ülke ve milletin en faziletli âlimleri ile ilgilenmeye devam eder. Onun meclisine katılan sohbet arkadaşları sanatçılar ve âlimlerden başkası değildir. Dostu olmayan cahiller onun meclisine yol bulamaz, tesadüfen böyle insanlarla karşılaşırsa bile onlar gözüne hafif görünür ve üzülür.

Emîr-i Kebîr'in kaleminden Hamse sâdir olmuştu ki, ona kadar Nizâmî'nin Hamsesi'ne cevap olarak kaleme alınan böyle bir eser yazmaya kimse cesaret edememiştir. Manaların kapısı gerçekten bu destanlarda açılmıştır. Gerçi Hüsrev Dehlevî de fazilet sahibidir; o hem gerçekler hem de hayalleri ilim ve hüner gücü ile kaleme almıştır ki, marifet sahibi nezdinde önem kazanmıştır. Fakat Amîr-i Kebîr de hamse yazma işinde şairliği, kalemperverliği vasıtasıyla hayaller üretmekte onlar (Nizamî ve Dehlevî)den asla geriye kalmamıştır.

Emîr-i Kebîr'in Türkçe divanlar da sultanlar ve büyüklerin meclislerine süs kazandırmıştır. Nevâ̂̀'nin nevâsı yolunu kaybetmiş kimsesiz âşılklara, gaybdan gelen doğru yolu gösterici ses olmuştur. Nevâ̂̀ dönemin mahbubudur. Onun ünü Hicâz'dan Nişapûr'a, oradan da İsfehân kadar yetişmiştir.

Buraya kadar özet olarak Emîr-i Kebîr'in fikrî olgunluğu, mütefekkirliği, tedbirkârlı̆̆l, fezîletleri, ilmî ve edebî konumundan bahsedildi. Şimdi kamu hizmet kuruluşları, Sadakât-ı câriyesini de çok klsa hatırlatalım:

Emîr-i Kebîr'in mimarî eserlerinin en göze çarpanlarl; Herat Dârü'lSeltenesi, Herat Camîsi, Herat Dergâh-ı Alîsi, Herat Medresesi, Herat Dârü'ş-Şifâsı, Herat Hamamı, Herat Nehri ve başka yüzlerce konak, kervan saray, köprü, çeşme, nehir ile onlarca mezarlıklardır." (Tezkiretü'ş-Şuerâ, Granville Browne: 494-508).

Tezkiredeki yaklaşık on beş sayfalık Nevâî maddesinde şair hakkında bilgi verilmekte ve divanlarından gazel, mesnevî ve beyitleri örnek olarak verilmektedir. Bunun dışında yazar eserinin 13 sayfalık mukaddimesinde, eserin yazılış sebebinden sonra Alî Şîr Nevâînnin cömertliği, vefalısı, şefkati, sevgisi, misafirperverliği, kalemperverliği gibi ahlâkî ve ilmî özelliklerinden bahsetmektedir. Devlet Şah eserini bitirip Nevâî'ye ithaf ettiğini, böylece kendini bahtiyar hissettiği dile getirmektedir.

hJ»hin - Бикмет - ت 


\section{Bâbür-Nâme'de Alî Sî̀r Nevâî:}

Babür Şah (ö.1530) ile Alî Şîr Nevâî’nin birbirleriyle fikrî-edebî yönleri, sosyal-siyasî konumları ve zaman-mekân açılarından ortak noktaları vardır. İkisi de aynı döneminde yaşamış, mektup vasıtası ile görüşmüş ve aynı dilin iki hükümdar şairi olmuşlardır.

Babür Şâh, Nevâ̂’'nin bütün eserlerini samimiyetle okumuş ve okumakla kalmayarak Alî Şîr Nevâî’yi kendi üstadı kabul edip gazellerini ezberlemiş ve onlara nazireler yazmıştır. Babür Şah eserlerinde Nevâî'den çokça bahsetmiştir. Özellikle Bâbür-Nâme eserinde yaklaşık 20 kere Nevâ̂̀'nin özellikle hayatındaki büyük olaylardan hassaten kişiliğinden bahsedilmiştir. Aşağıdaki metin söz konusu kaynaktan Nevâî ile ilgili kısa bir tercümedir:

"Alî Şî̀ Bek benzeri olmayan bir kişiydi. Türk diliyle şiirler yazmıştır. Hiç kimse onun kadar hem nitelik hem de nicelik açısından yüksek değildir. Altı mesnevî yazmıştır. Beş tanesi Hamse'nin cevabl, bir tanesi ise "Mantıku't-Tayr" cevabı olan "Lisânü't Tayr"dir. Dört tane Türkçe divan tertip etmiştir ki, (Garâibü's-Sigar, Nevâdirü'ş-Şebâb, Bedâyi'u'l-Vâsat Fevâidü'l-Kiber) olarak adlandırmıştır.

Güzel rubaileri vardır. Niteliği düşük ve sağlam olmayan bazı terkipleri da vardır. Münşeatını Abdurrahman Câmî'den taklitle yazmıştır. Aslında bu eser, başkalarına yazdığı mektupların bir araya getirilmiş hâlidir. Mizânü'lEvzân isimli bir aruz kitabı da yazmıştır. Bu eseri çok önemlidir. (Aruz ilmine ait Türkçe olarak ilk mükemmel kitaptır) Dört yerde yanılmıştır ki, bu hususlar aruz ilmi ile aşina olanlara malumdur.

Nevâ̂̀ Farsça divan da tertip etmiştir. Farsça şiirlerinde "Fânî" mahlasını kullanmıştır. Bazı beyitleri iyi sayılmakla birlikte çoğu beyitleri güçsüzdür.

Şimdiye kadar hiç kimse âlim ve sanatkârları Alî Şîr Bek kadar desteklememiştir. Hüseyin Baykara ve Udî Bek, Alî Şîr Bek'in destek ve önderliği ile bu kadar gelişip meşhur olmuştur. Üstad Behzâd dahi resim sanatında Alî Şîr Bik'in desteği ve gayreti ile şöhret kazanmıştır. Onun imar ettirdiği hayır binalarını hiç kimse yapamaz ve bu hayrı başaramazdı.

Alî Şîr Bek'in oğlu ve klzı yoktur. Evlenmemiş ve aile de kurmamıştır. Dünyevî hayatını evlenmeden tek başına geçirmiştir."(Babürnâme, Beveridge, 1922: 271-272).

Görüldüğü üzere Babür Şâh da Alî Şîr Nevâî’nin diğer çağdaşları gibi onu farklı münasebetlerle anarak hakkında pek değerli bilgiler kaydetmiş̧tir ki, Nevâî’nin sanat yönü başta olmak üzere eserleri, eserlerinin niteliği, zamanındaki etkisi, ünü ve hatta özel hayatına bile ışık tutmuş olmaktadır.

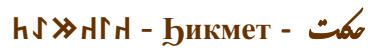

HIKMET - AKADEMIK EDEBiYAT DERGisi [ JOURNAL OF ACADEMIC LITERATURE]

ISSN: 2458 - 8636 


\section{B. ALÎ ŞîR NEVÂ̂̂’'NİN BİLİNMEYEN ÜÇ ESERİ}

Alî Şîr Nevâî'nin eserleri ilmî, sosyal, siyasî, dinî-tasavvufî, ahlâkî-didaktik konuları içermektedir. Bu husus onun şahsiyetinin çok yönlü olduğunun bir göstergesidir. Ancak Türk dünyasında daha çok edebî yönü ile özel bir yere sahiptir. Nevâî'nin hayatında mensup olduğu milletinin, o milletin zengin dilinin, yaşadığı toprakların ruh ikliminin, özellikle kültürü ve edebiyatının özgün bir yeri vardır.

Bugüne kadar Türkiye'de yapılan akademik çalışmalarda şairin eserleri ile ilgili; "Alî Şîr Nevâîee nin toplam 29 eseri mevcuttur"3 (Bulut, 2017: 40) kanaati kabul görülürken, bizim bu çalışmamızla birlikte tanıtılan (MünşeâtFârisî ile Risâle-i Müfredât-ı Muamma, Risâle-i Tîr-Andâhtan) risalelerle Nevâî'ye ait eserler sayısı 31 'e çıkmış olacaktır.

Şimdi bu risaleleri tanıtalım.

\section{Risâle-i Münşeât-ı Fârisî:}

Bu münşeât, Baykara sarayında alınan kararlar, Nevâînnin Herat'tan başka şehirlere gönderdiği resmi ve özel belgeler, mektuplar, hüküm ve emirlerden ibarettir.

$\mathrm{Bu}$ dönemde, özellikle Baykara sarayında yazılan inşalar sade ve kısa olduğundan Nevâî de eserinde aynı yolu izlemiştir. Bunun yanı sıra edebî sanatlar, seci, ayet ve hadisler, Arapça kalıp ibarelerden hayli istifade etmiştir. Aynı zamanda münşi inşalarının muhtevasını pekiştirmek ve güçlendirmek için kendine ait şiirlere de yer vermiştir.

Alî Şîr Nevâi yazdığı mektup veya namelerinde muhatabının siyasî, edebî, ilmî, dinî veya sosyal konumunu dikkate almıştır. Örneğin, Sultan veya herhangi bir devlet adamına yazdığı inşasında, karşı taraftakinin konumuna muhakkak değinmiş ve şanına değer saygısını açıkça beyan etmiştir. Şayet muhatabı ilmî zümreye ait biri değilse, konumunun önemini de dikkate alarak pek sade ve öz yazmayı tercih etmiştir. Nevâî’nin mektuplarını, ne kendisi ne de dönemindeki herhangi biri toplamıştır. $\mathrm{Bu}$ inşalar İran'ın farklı kütüphanelerinde bulunan el yazma nüshaların birleştirilmiş halidir. Aslında yazarın kendi eserlerinde veya döneminde kaleme alınmış başka kaynaklarda, böyle bir eserin telif edildiği ile ilgili bilgi bulunmamaktadır.

Risâle-yi Münşeat-ı Farisi'de yer alan mektup ve inşâların bazıları şöyledir:

${ }^{3}$ Hayretü'l-Ebrâr, Ferhad ü Şîrîn, Leylî ve Mecnûn, Seb'a-i Seyyâre, Sedd-i İskenderî, Garâibü's-Sigar, Nevâdirü'ş-Şebâb, Bedâyi'u'l-Vasat, Fevâidü'l-Kiber, Lisanü’t-Teyr, Divan-1 Fânî, Mahbûbu'l-Kulûb, Nesâyimü'l-Mahabbe, Mecâlisü'n-Nefâyis, Muhâkemet'ülLugateyn， Mîzânü'l-Evzân，Münâcât，Cihil-Hadîs，Nazmü'l-Cevâhir，Sirâcü'l-Müslimîn, Tarih-i Mülûk-1 Acem, Tarih-î Enbiyâ vü Hükemâ, Zübdetü’t-Tevârih, Hâlât-1 Seyyid Hasan Erdeşîr, Hâlât-1 Pehlivan Muhammed, Hamsetü'l-Mütehayyirîn, ?Vakfiyye, Türkçe Münşeât.

hJ»hin - Бикмет - ت

HİKMET - AKADEMIK EDEBIYAT DERGisi [ JOURNAL OF ACADEMIC LITERATURE]

ISSN: 2458 - 8636 
Nevâî ile Abdurrahman Câmî arasında farklı münasebetlerle karşılıklı kaleme alınmış inşalar, sarayda mühürdar ve vezir iken şehirlerin vali veya kadılarına gönderdiği hükümler, özellikle sarayın hazine ve ülkenin maliyesinden sorumlu olduğu dönmelerde farklı nedenlerle gönderdiği kararnameler başta olmak üzere, Nevâi’nin Hâce Efdel Kirmânî’ye, Hint valisi Şeref Han'a, Ebul Hasan Bin Abdullah'a yazdığı mektuplar, herhangi şehrin kütüphanesi ile ilgili yazılan mektup, Baykara sarayından görevinden ayrılırken yazıp bıraktığı istifa belgesi, Sultan Yakup isimli bir kişiye yazdığı nâme vb.lerinin bir araya getirilmiş halidir. En dikkat çekici mektup ise Baykara'nın emriyle Herat'ta yaşamakta olan bir Hristiyan rahibine yazdığ1 mektuptur. (Merkez-i Püjûhişi-yi Mirâs-1 Mektup, http://www.mirasmaktoob.ir/fa/news/4976, Erişim Tarihi: 01. 12. 2018.)

Eser, ilk kez Muhammed Hüseyin Sıdık tarafindan yazılan bir mukaddime ve Menije Muhammed-Dâdî tarafından hazırlanan edisyonkritikli metin olarak İran'da basılmıştır. (Bkz. Muhammed Hüseyin Sıdık ve Menije Muhammed-Dâdî. (2015), Alî Şîr Nevâî, Risâle-i Münşeât-1 Farisî, İnti Şârât-1 Tek-Direht Yayınları).

\section{Risâle-i Müfredât-ı Muamma:}

Adından da anlaşılacağı üzere Nevâî bu risâleyi dönemin meşhur türlerinden biri olan muammanın kaide ve kurallarını, muamma söylemeyi ve muamma çözmeyi şiir dünyasına yeni giren gençlere öğretmek amaciyla yazmıştır. Dili Farsça olan bu eserden Agâh Sırrı Levend bahsetmemiştir.

Eser 122 sayfa olarak İran'da Emir Nimeti ve Mehdi Kasım Neyâ tarafindan bir mukaddime ve edisyon-kirtikli bir metin olarak Müşkat-i Daniş yayınevi tarafından yayımlanmıştır. (https://www.farsnews.com/news/13940503001032, Erişim Tarihi: 02.12.2018). (Bkz. Risâle-i Müfredat-i Muamma: 2015) Risâle-i Müfredat-i Muamma'nın mukaddime kısmının tercümesi şöyledir:

"Bismillahirrahmânirrahîm

Nâme-i feth-est zihī kedîm

Ta'miye der-ism müsemmast in

Allah Allah çi-muamma-st in"”

"Ondan sonra şöyle 'arz edilir ki, bu latif zaman ve şerif devranda muamma ilmi şayi olmuş, letafeti ve dikkat çekici olması haddinden aşmıştır. Çocuklar ve Etrâk'in hevesi ve ilgi göstermesi, ancak gayet nazik ve zor olması, fakirin (Nevâî) aklına geldi ki, muhtasar ki, açıklanması kolaylaşsın. Şu noktaya dikkat edilsin ki, her muamma kuralı söylendiğinde getirilen örnek de sadece o muamma kuralına girer. Ancak bir-iki istisna kaide vardir $k i$, şairin onları atlaması veya vazgeçmesinden başka tedbiri yoktur, aslında bu istisnalar okuyucunun da zihnini aksatmıyor... Fakat çocukların işlerine

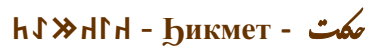

HİKMET AKADEMIK EDEBIYAT DERGisi [ JOURNAL OF ACADEMIC LITERATURE]

ISSN: 2458 - 8636 
kolaylık sağlayacaktır... Muamma türü, vezinli ve ahenkli bir kelamdır... Muamma üç çeşittir..." (Nevâ̂,, Risâle-i Müfredat-i Muamma, https://goo.gl/images/6EZZ3E, Erişim Tarihi:01.12.2018).

olarak bir yazı hazırlanmalı. Kaidelerin her birinde örnek olarak birkaç muamma getirilsin

\section{Risâle-i Tîr Andâhtan:}

Hacim bakımında oldukça kısa olan bu Türkçe eserde, ok atmanın yararları ve sevabı, Hz. Peygamber ile sahabeler ve Cebrail arasinda ok atmaya dair geçekleşmiş sohbetler ve özellikle Hz. Vakkâs ile Hz. Peygamber arasındaki ok atma denemelerinden bahsedilmiştir. Söz konusu risâle Özbekistan Fenler Akademisi tarafından hazırlanmış olan 20 ciltlik külliyatın 16. cildinin sonunda yer almaktadır. Fakat Agâh Sırrı Levend'in kitabında esere dair bilgi yoktur.

Yaklaşık iki sayfalık bu risâle, çok kısa olduğundan dolayı, Nevâî’nin kalemine ait olup olmadığı araştırmacılar tarafından değerlendirilmiştir. En önemlisi, Özbekistan'l1 Nevâî konusunda uzman Suyime Ganiyeve ve Orfan Atacan, Risâle-i Tîr Andâhtan'1 farklı açılardan incelemiş, sonunda Alî Şîr Nevâî'ye ait olduğuna kesin karar vermişlerdir. Bu değerlendirmenin özeti şöyledir:

“Ali Şîr Nevâ̂’’nin eksik olan külliyatında Risâle-i Tîr Endâhten adlı bir eser bulunmaktadır. Bu risalenin başka nüshaları da mevcuttur. Ünlü Rus oryantalisti Yevgeni Bertels "Nevâ̂" adlı kitabında şaire ait 22 eser sıralamıştır. Bu listenin sonunda, aslında Türkçe olduğu sanılan Risâle-i Tîr Endâhten' in Farsça olduğunu kaydetmektedir.

Ali Şîr Nevâî'nin 1667-70. yıllarında istinsah edilmiş 17 eserini içeren bir külliyatı Suyime Ğaniyeva'nin elinde de mevcuttur. Söz konusu külliyatın 151-152. sayfalarında Risâle-i Tîr Endâhten de kaydedilmiştir. Ğaniyeva bu risâle hakkında Nevâî konusunda uzman Parsa Han Şemsiyev ile görüşmüş fakat Şemsiyev bu eserin Alî Şîr Nevâî’ye ait olmadığını ve bu risâlenin herhangi bir rivayet-nâme tarzındaki eserden aktarılmış bir parça olabileceğini ileri sürmüştür. Aynı şekilde şair Gafur Gulam da bu eserin Alî Şîr Nevâînnin olduğunu kesinlikle reddetmiştir." (Ganiyeve ve Atacan, 1995:122-125)

Biz ise şu delilleri esas alarak söz konusu risâlenin Nevâ̂’’ye ait olduğunu iddia ediyoruz:

- Öncelikle E. Bertels ve A. Semyonov gibi tanınmış oryantalistler bu risâlenin Alî Şîr Nevâî'nin kalemine ait olduğunu ifade etmişlerdir.

- Bilindiği üzere Nevâî, Hz. Peygamberimizin hadislerini çok iyi bilir ve bu konuda Kırk-Hadîs adlı risâlesi de vardır. Bundan yola çıkarak Nevâî, Risâle-i Tîr-Endāhten avcılığın ehemmiyetine dair bir hadisin şerhi olabilir.

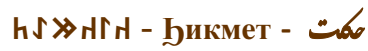

HİKMET AKADEMIK EDEBIYAT DERGisi [ JOURNAL OF ACADEMIC LITERATURE]

ISSN: 2458 - 8636 
- $\quad$ Ali Şîr Nevâî başta ok ve yay olmak üzere harp aletlerini çok iyi kullanmış ve yiğitlik dönemlerinde Hüseyin Baykara ile bazı savaşlara da katılmıştır.

Özetle, Alî Şîr Nevâî’ye ait olduğu delillerle sabit olan bu risâlenin hazırlanıp ilim âlemine sunulması faydalı olacaktır.

\section{SONUÇ}

Alî Şîr Nevâî Doğu dünyasının parlak şahsiyetlerinden biridir. İslam medeniyeti çerçevesinde yetişen İran edebiyatı için Sadi-i Şirazî, Hafiz-1 Şirazî, Nizâmî, Hüsrev-i Dehlevî, Abdurrahman-1 Câmî, Attar, Mevlânâ; Batılı edebiyatı için William Shakespeare, Dante, Alexander Puşkin ve Homeros gibi şahsiyetler ne ise, hiç şüphesiz Alî Şîr Nevâi de Türk edebiyatı için odur diyebiliriz.

Nevâî sadece doğduğu bölge veya ait olduğu dilin edibi, şairi ve sanatçısı olmakla sınırlı kalmamış aynı zamanda yazdığı eserleri ve delili olarak yaptırdığ 360 adet kamu hizmet kuruluşu, 15. asır Horasan'ının merkezi Herat'1 Doğu Rönesans'ının merkezine dönüştürmeyi başarmıştır. Aynı zamanda Herat mektebini kurmuş ve yazdığı eserleri ile Çağatayca'nın kendi adı yani "Nevâî dili" ile anılmasını sağlamıştır.

Dönemin Padişahı Sultan Hüseyin Baykara Risale eserinde Nevâî ile ilgili; hak sözünü söyleyen bir cesur, Türk dilinin sahibi ve Türk adetgeleneklerinin yegâne hamisi ve eserleri ulaştığı ülkeleri fetheden bir yiğit olduğunu dile getirmiştir. Hemen ardından Nevâî'nin şiirlerinin içeriğine dair bazı açıklamalarda bulunmuş. Kendi döneminde Nevâî gibi büyük ilmî ve edebî şahsiyet onun veziri olarak yanında olduğundan gurur duyduğunu ifade etmiş. Ülkesi ve dönemine onur kazandırdı̆̆ını dile getirmiştir. Hülasa Baykara, Nevâî'nin sosyal konumu, ilmî-edebî çalışmaları ve siyasî görevleri hakkında etraflıca malumat vermiştir.

15. yüzyıl şair tezkirecisi Devlet Şah-Semerkandî ise Tezkire'sinde, Nevâî ile aynı dönemde yaşayıp onun maddî-manevî desteklerinden yararlanan ve onunla doğrudan ilmî-edebî ilişkilerde olan biri olarak, Nevâî'nin biyografisinden ziyade; mütefekkir kişiliği, tedbirli tutumu, kişisel faziletleri hakkında şahit olduklarını dile getirmiştir. Özellikle ilmi, yetenekleri, şairliği, sosyal çevresi, yardımseverliği, bilim ve sanat sahiplerini destekleyicisi olduğundan bahsetmiştir. Bunun yanı sıra devletteki konumu, padişah ile olan her yönlü ilişkisi, saltanatın yönetim ve denetimindeki rolü, vezirler ve şehzadelerle olan işbirliği, din-tasavvufla olan münasebeti, halka hizmet için yaptığı hayır işler gibi konuları gözlemlerini kaydetmiştir.

Zehireddin Muhammed Babür Babür-Nâme isimli eserinde: daha çok Nevâî'nin biyografisi, devlet veya siyasî işlerinden ziyade, onun ilmî-edebî faaliyetlerine önem vermiş ve eleştirel bir gözle bakarak hayli dikkat çekici

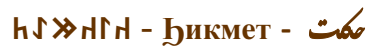


malumat aktarmıştır. Yine Nevâî'nin kaleme aldığı altı mesnevi, altı divanı ve imar ettirdiği binalardan övgüyle bahsetmiştir. Bununla beraber Alî Şîr Nevâî rubailerinde edebi eksiklikler ve inşa zayıflığı olduğunu ifade etmiş, Mizânü'l-Evzân eserinde bazı vezinlerde hata yaptığını, Münşeât eserini ise başkasından taklit ederek kaleme aldığını, bazı Farsça şiirleri Türkçe şiirleri kadar güzel olmadığını açıkça beyan etmiştir.

Çalışmamızın ikinci kısmında; Nevâ̂̂’ye ait tanıtılan eserlerden biri Risâle-i Münşeât-ı Fârisî̀dir. Resmî ve gayri resmî mektup veya namelerinden oluşan bu risale: siyasî, edebî, ilmî, dinî, şahsiyetler ve dostları ile yazışmalarıdır. Mektup ve namelerin üslubu sade olmakla beraber ayet, hadis ve kendine ait şiir parçalardan da bolca kullanmıştır. Söz konusu risaledeki mektupların tümü Meryem Hudadâdî emeği ile İran'daki farklı kütüphanelerden el yazma parçaları toplanarak 2017 yılından basılmıştır.

İkinci eser ise; Risâle-i Müfredât-ı Muamma'dır. Risale Muamma türünde yazılmışıır. Muamma türünde şiir söyleyen genç şairler kuralları pek bilmedikleri için bu risaleyi kaleme aldığını söylemiştir. Söz konusu risale Emir Nimeti ve Mehdi Kasım Neyâ tarafindan bir mukaddime ve edisyonkirtikli İran'da basılmış durumdadır.

Üçüncü de; ok atmanın faziletleri ve önemine dair kaleme alınan Risâle- $i$ Tîr Andâhtan isimli risaledir ki; bu kısa risalenin dili Çağatayca'dır. Hz. Peygamber ile sahabeler ve Cebrail arasındaki ok kullanımı üzerine diyaloglardan oluşmaktadır. Özellikle Hz. Vakkâs ile Hz. Peygamber arasındaki ok atmaya dair mensur hikâyelerden müteşekkildir.

$\mathrm{Bu}$ çalışmanın bir sonucu olarak ta; bugüne kadar Alî Şîr Nevâînnin eserlerine dair yapılan akademik çalışmalarda “Ali Şîr Nevâ̂’’nin toplam 29 eseri vardır" cümlesine tanıttığımız üç eserde ilave olunarak "Ali Şîr Nevâ̂'’nin toplam 31 eseri vardır" denilmelidir.

\section{KAYNAKÇA}

Algar Hamid ve Alparslan Ali. (1998), "Hüseyin Baykara", DİA, C. 18, Türkiye Diyanet Vakfı Yayınları, İstanbul.

Âşık, Muhammed Ekber. (1955), Hand Mîr, Makârimü'l-Ahlâk Şerh-1 Ahvâl ve Zendegâni Amîr Alî Şîr Nevâî, Miras-1 Mektup Yayınları, Tahran.

Barutçu Özönder, Sema. (1996), Alî Şîr Nevâî, Muhâkemetü'l-Lügateyn, TDK Yayınları, Ankara.

Bulut Serdar. (2017), "Asya Coğrafiyesinin Büyük Edibi Alî Şîr Nevâînnin Hayatı, Edebî Kişiliği Ve Eserleri ve Türk Diline Katkıları", Akademik Sosyal Araştırmalar Dergisi, Sayı 1.

Çetindağ, Yusuf (2006). Alî Şîr Nevâî’nin Osmanlı Şiirine Etkisi, T.C. Kültür ve Turizm Bankalığı Yayınları, Ankara.

Emir Nimetî ve Mehdi Kasım Niyâ. (2015), Alî Şîr Nevâî, Risâle-i Müfredat-i Muamma, İntişârât-1 Müşkûh-i Dâniş, Tahran.

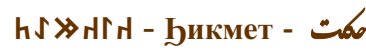

HIKMET AKADEMIK EDEBiYAT DERGisi [ JOURNAL OF ACADEMIC LITERATURE]

ISSN: 2458 - 8636 
Granville Browne Edward. (1965), Devletşâh Semerkandî Tezkiretü'şŞuarâ'sı, Esatîr Yayınları, Tahran.

Kartal, Ahmet (2003). "Alî Şîr Nevâî'nin Farsça Şiirleri”. Bilig, S. 26. s. 146-180.

Kazi, Abdurrahim, (1387 H.). "Nevâî Nizâmülmülk-i Sâni”, Tarih-i Pujuhişi Dergisi, S. 36.

Köktekin, Kazım. (2002). “Ali Şîr Nevâî’nin Türkçeçiliği”, A.Ü. Türkiye Araştımaları Enistitüsü Dargisi, S. 19.

Levend, Agâh Sırrı (1965). Alî Şîr Nevâî Hayatı, Sanatı ve Kişiliğii, I. cilt, TDK Yayınları, Ankara.

Levend, Agâh Sirrı. (1966), Alî Şîr Nevâî, 4-Türkçe 1-Farsça Divanı, II. cilt, TDK. Yayınları, Ankara.

Levend, Agâh Sırrı. (1967), Alî Şîr Nevâî, Hamse, III. cilt, TDK. Yayınları, Ankara.

Levend, Agâh Sırrı (1968), Alî Şîr Nevâî Divanlar ile Hamse Dışındaki Eserler, IV. cilt, TDK Yayınları. Ankara.

M. Mirza. (2000), Alî Şîr Nevâî, Mahâkemetü'l-Lügateyn, Mîzânü'l-Evzân, Tarih-î Enbiyâ vü Hükemâ, Tarih-i Mülûk-1 Acem, Erbain, Sirâcü'lMüslimîn, Türkçe Münşeât, Risâle-i Tîr Andahtan, C. 16, (20 ciltli Mükemmel Eserler Toplamı), Özbekistan Fen Neşriyatı Yayınları, Taşkent.

Muhammed Hüseyin Sıdık ve Menije Muhammed-Dâdî. (2015), Alî Şîr Nevâî, Risâle-i Münşeât-1 Farisî, İntiŞârât-1 Tek-Direht, Tahran.

Özcan, Hüseyin, "Türk Dünyasının Bilgesi Alî Şîr Nevâ̂’, Ölümünün 500. Y1lında Alî Şîr Nevâî Sempozyumu, Özbekistan.

Susannah Beveridge Annete. (1922), Babürnâme, LUZAC Yayınları. Londra.

Sümeyye Ganiyeve ve Urfan Atacan, (1995) “Ali Şîr Nevâî, Risâle-î Tir Andahtan" Tefekkür gazetesi (editör: İrkin Azam), Şark Neşriyatı, Taşkent, s. 122-125.

Tarlan, Ali Nihat (1942). Alî Şîr Nevâî. İstanbul: Doğu Türkistanlılar Cemiyeti Yayınları.

Vahidov, Raman ve İşançkulov Husniddin. (2000), Özbek Mümtaz Edebiyatı Tarihi, Özbek Yazıcılar Neşriyatı Yayınları, Taşkent.

Vahidi Cevzicanî Yakup. (1925), Hüseyin Baykara Divanı ve Risâle eseri, Teb'-i Kütûb Yayınları, Kabil. 